\title{
STRATEGI PENGENTASAN KEMISKINAN DALAM PERSPEKTIF ISLAM
}

\author{
Sri Budi Cantika Yuli \\ Mahasiswa Pascasarjana Fakultas Ekonomi \& Bisnis Universitas Airlangga \\ E-mail: cantikayuli@yahoo.com
}

\begin{abstract}
Islamic perspective views poverty as a result of several structural reasons, namely environmental damage due to human activity (Surah Ar Rum: 41); ignorance and the miserliness of the wealthy (Surah Al 'Imran: 180); tyranny, exploitation, and oppression of some people over others (Surah At-Tawbah: 34); political, bureaucracy, and economic power concentration in one hand (Surah Al Qasas; 1-88); poverty arising from external factors such as natural disaster or civil wars that drastically changed the rich become poor (Surah Saba ': 14-15). Islam proposes some strategies in order to reduce poverty which covers: 1) Promoting economic growth that benefits to the wider community (pro-poor growth); 2) Encouraging the construction of national budget which protect majority of people (pro-poor budgeting); 3) Assisting infrastructure development that aids many people (pro-poor infrastructure); 4) Establishing proper basic public services in favor of the broader community (pro-poor public services); and 5) Pushing equity and income distribution policies that prioritize the poor (pro-poor income distribution).
\end{abstract}

Keywords: Poverty, Structural Poverty, Economic Growth, Equity, Income Distribution

\begin{abstract}
Abstrak
Dalam perspektif Islam, kemiskinan timbul karena sebab struktural, yaitu karena kejahatan manusia terhadap alam (QS Ar Ruum:41); ketidakpedulian dan kebakhilan kelompok kaya (QS Ali Imran:180); sebagian manusia bersikap dzalim, eksploitatif, dan menindas kepada sebagian manusia yang lain (QS At Taubah:34); konsentrasi kekuatan politik, birokrasi, dan ekonomi di satu tangan (QS Al Qashash;1-88); kemiskinan timbul karena gejolak eksternal seperti bencana alam atau peperangan sehingga negeri yang semula kaya berubah menjadi miskin. (QS Saba': 14-15). Strategi pengentasan kemiskinan dalam perspektif Islami meliputi: 1) Mendorong pertumbuhan ekonomi yang memberi manfaat luas bagi masyarakat (pro-poor growth); 2) Mendorong penciptaan anggaran negara yang memihak kepada kepentingan rakyat banyak (pro-poor budgeting); 3) Mendorong pembangunan infrastruktur yang memberi manfaat luas bagi masyarakat (pro-poor infrastructure); 4) Mendorong penyediaan pelayanan publik dasar yang berpihak pada masyarakat luas (pro-poor public services); dan 5) Mendorong kebijakan pemerataan dan distribusi pendapatan yang memihak rakyat miskin (pro-poor income distribution).
\end{abstract}

Kata kunci: Kemiskinan, Kemiskinan Struktural, Pertumbuhan Ekonomi, Pemerataan, Distribusi pendapatan 
Kemiskinan yang terjadi dalam masyarakat dapat dikelompokkan menjadi lima penyebab. Pertama, Pandangan Alamiah Lingkungan, yang menekankan bahwa penyebab kemiskinan karena lingkungan sumberdaya yang tersedia memang miskin, lahan kritis dan masyarakat miskin tidak berdaya/ tidak memiliki akses yang kuat, dan lain lain. Kedua, Pandangan Spesifik Lokasi, yang menekankan bahwa penyebab kemiskinan adalah terletak pada faktor lokasi yang terpencil tidak terjangkau oleh program pembangunan dan tidak menjadikan spesifik lokasi sebagai alternatif pendekatan dalam pembangunan. Ketiga, Pandangan Struktural, yang menekankan bahwa penyebab kemiskinan adalah terletak pada faktor struktur sosial ekonomi dalam masyarakat. Keempat, Pandangan Kultural, yang menekankan bahwa penyebab kemiskinan adalah terletak pada kultur masyarakat miskin, seperti malas, tidak mau bekerja keras, tidak ulet, dan lain-lain. Kelima, Pandangan Organisasi dan Kelembagaan, yang menekankan bahwa penyebab kemiskinan terletak pada faktor akses organisasi masyarakat miskin yang lemah secara ekonomi, sosial, budaya dan bahkan politik.

Pengalaman di beberapa negara Asia menunjukkan berbagai model mobilisasi perekonomian pedesaan untuk memerangi kemiskinan, yaitu: Pertama, mendasarkan pada mobilitas tenaga kerja yang masih belum didaya gunakan (idle) dalam rumah tangga petani gurem agar terjadi pembentukan modal di pedesaan (Nurkse, 1953). Tenaga kerja yang masih belum didayagunakan pada rumah tangga petani kecil dan gurem merupakan sumberdaya yang tersembunyi dan potensi tabungan. Alternatif cara untuk memobilisasi tenaga kerja dan tabungan pedesaaan adalah: 1) menggunakan pajak langsung atas tanah, seperti yang dilakukan di Jepang. 2) dilakukan dengan menyusun kerangka kelembagaan di pedesaan yang memungkinkan tenaga kerja yang belum didayagunakan untuk pemupukan modal tanpa perlu menambah upah. Ini persis yang dilakukan Cina yang menerapkan sistem kerjasama kelompok dan brigades ditingkat daerah yang paling rendah (communes). Dengan metode ini ternyat memungkinkan adanya kenaikan yang substansial dalam itensitas tenaga kerja dan produktivitas tenaga kerja.

Model kedua, menitik beratkan pada tranfer daya dari pertanian ke industri melalui mekanisme pasar (Fei \& Gustav, 1964). Ide bahwa penawaran tenaga kerja yang tidak terbatas dari rumah tangga petani kecil dapat meningkatkan tabungan dan formasi modal lewat proses pasar. Pengalaman Taiwan menyajikan contoh yang baik atas mobilisasi sumber daya dari sektor pertanian mengandalkan mekanisme pasar, tanpa menggunakan instrumen pajak seperti yang dilakukan oleh Jepang. Proporsi output sektor pertanian sebagian besar tetap dijaga sebagai surplus lewat intermediasi pemilik tanah dan melalui nilai tukar (terms of trade) sebelum Perang Dunia II.

Model ketiga, menyoroti pesatnya pertumbuhan dalam sektor pertanian yang dibuka dengan kemajuan teknologi dan kemungkinan sektor yang memimpin (Mellor, 1976), Model ini dikenal dengan nama Model Pertumbuhan Berbasis Teknologi, atau Rural-Led Development. Proses ini akan berhasil apabila dua syarat berikut terpenuhi: 1) kemampuan mencapai tingkat pertumbuhan output pertanian yang tinggi; 2) proses ini juga menciptakan pola 
permintaan yang kondusif terhadap pertumbuhan. Pada gilirannya ini tergantung dari dampak keterkaitan ekonomi pedesaan lewat pengeluaran atas barang konsumsi yang dipasok dari dalam sektor itu sendiri, dan melalui invesatasi yang didorong.

Model keempat, menyoroti dimensi spasial dalam menanggulangi kemiskinan. Kemiskinan bisa diatasi dengan cara kemudahan dalammengakses dua bidang, yaitu: 1) bidang ekonomi dan 2) bidang sosial (Kuncoro, 2004). Akses dalam bidang ekonomi dibagi menjadi dua yaitu: akses terhadap lapangan kerja dan akses terhadap faktor ekonomi. Akses terhadap faktor produksi terdiri dari: 1) Kemudahan masyarakat dalam mengakses modal usaha, 2) kemudahan masyarakat dalam mengakses pasar, 3) kemudahan masyarakat dalam kepemilikanmodal. Sedangkan akses dalam bidang sosial dibagi menjadi dua yaitu: akses terhadap fasilitas pendidikan dan akses terhadap fasilitas kesehatan.

\section{Kemiskinan Dalam Perspektif Islam}

Menurut bahasa, miskin berasal dari bahasa Arab yang sebenarnya menyatakan kefakiran yang sangat. Allah SWT menggunakan istilah itu dalam firman-Nya:

"..atau orang miskin yang sangat fakir" (QS al-Balad [90]: 16)

Adapun kata fakir yang berasal dari bahasa Arab: al-faqru, berarti membutuhkan (al-ihtiyaaj). Allah SWT berfirman: "...lalu dia berdoa, "Ya Rabbi, sesungguhnya aku sangat membutuhkan suatu kebaikan yang Engkau turunkan kepadaku” (QS al-Qashash [28]:24).

Dalam pengertian yang lebih definitif, Syekh An-Nabhani mengategorikan yang punya harta (uang), tetapi tak mencukupi kebutuhan pembelanjaannya sebagai orang fakir. Sementara itu, orang miskin adalah orang yang tak punya harta (uang), sekaligus tak punya penghasilan. (Nidzamul Iqtishadi fil Islam, hlm. 236, Darul Ummah-Beirut). Pembedaan kategori ini tepat untuk menjelaskan pengertian dua pos mustahiq zakat, yakni al-fuqara (orang-orang faqir) dan almasakiin (orang-orang miskin), sebagaimana firman-Nya dalam QS at-Taubah [9]: 60

"Sesungguhnya zakat-zakat itu, hanyalah untuk orang-orang fakir, orang orang miskin, pengurus-pengurus zakat, para muallaf yang dibujuk hatinya, untuk (memerdekakan) budak, orangorang yang berutang, untuk jalan Allah dan orang-orang yang sedang dalam perjalanan, sebagai sesuatu ketetapan yang diwajibkan Allah; dan Allah Maha Mengetahui lagi Maha Bijaksana"

Kemiskinan atau kefakiran adalah suatu fakta, yang dilihat dari kacamata dan sudut mana pun seharusnya mendapat pengertian yang sesuai dengan realitasnya. Sayang peradaban Barat Kapitalis, pengemban sistem ekonomi Kapitalis, memiliki gambaran/fakta tentang kemiskinan yang berbeda-beda. Mereka menganggap bahwasannya kemiskinan adalah ketidakmampuan untuk memenuhi kebutuhankebutuhan atas barang ataupun jasa secara mutlak. Karena kebutuhan berkembang seiring dengan berkembang dan majunya produk-produk barang ataupun jasa, maka -mereka menganggap-usaha pemenuhan kebutuhan-kebutuhan atas barang dan jasa itu pun mengalami perkembangan dan perbedaan.

Akibatnya, standar kemiskinan/ kefakiran di mata para Kapitalis tidak memiliki batasan-batasan yang fixed. DiAS 
atau di negara-negara Eropa Barat misalnya, seseorang yang tidak dapat memenuhi kebutuhan-kebutuhan sekundernya sudah dianggap miskin. Pada saat yang sama, di Irak, Sudan, Bangladesh misalnya, seseorang yang tidak dapat memenuhi kebutuhan sekundernya, tidak dikelompokkan dalam kategori fakir/miskin. Perbedaanperbedaan ini-meski fakta tentang kemiskinan itu sama saja di mana pun-akan mempengaruhi mekanisme dan cara-cara pemecahan masalah kemiskinan.

Berbeda halnya dengan pandangan Islam, yang melihat fakta kefakiran/ kemiskinan sebagai perkara yang sama, baik di Eropa, AS maupun di negeri-negeri Islam. Bahkan, pada zaman kapan pun, kemiskinan itu sama saja hakikatnya. Oleh karena itu, mekanisme dan cara penyelesaian atas problem kemiskinan dalam pandangan Islam tetap sama, hukumhukumnya fixed, tidak berubah dan tidak berbeda dari satu negeri ke negeri lainnya. Islam memandang bahwa kemiskinan adalah fakta yang dihadapi umat manusia, baik itu muslim maupun bukan muslim.

Islam memandang bahwa masalah kemiskinan adalah masalah tidak terpenuhinya kebutuhan-kebutuhan primer secara menyeluruh. Syariat Islam telah menentukan kebutuhan primer itu (yang menyangkut eksistensi manusia) berupa tiga hal, yaitu sandang, pangan, dan papan. Allah SWT berfirman:

"Kewajiban ayah adalah memberikan makan dan pakaian kepada para ibu dengan cara yang makruf” (QS alBaqarah [2]:233)

"Tempatkanlah mereka (para istri) di mana kamu bertempat tinggal, sesuai dengan kemmpuanmu” (QS ath-Thalaaq [65]:6)
Rasulullah SAW Bersabda "Ingatlah, bahwa hak mereka atas kalian adalah agar kalian berbuat baik kepada mereka dalam (memberikan) pakaian dan makanan" (HR Ibnu Majah).

Dari ayat dan hadis di atas dapat di pahami bahwa tiga perkara (yaitu sandang, pangan, dan papan) tergolong pada kebutuhan pokok (primer), yang berkait erat dengan kelangsungan eksistensi dan kehormatan manusia. Apabila kebutuhan pokok (primer) ini tidak terpenuhi, maka dapat berakibat pada kehancuran atau kemunduran (eksistensi) umat manusia. Karena itu, Islam menganggap kemiskinan itu sebagai ancaman yang biasa dihembuskan oleh setan, sebagaimana firman Allah SWT: "Setan menjanjikan (menakut-nakuti) kamu dengan kemiskinan" (QS al- Baqarah [2]:268).

Dengan demikian, siapa pun dan di mana pun berada, jika seseorang tidak dapat memenuhi kebutuhan pokok (primer)nya, yaitu sandang, pangan, dan papan, dapat digolongkan pada kelompok orangorang yang fakir ataupun miskin. Oleh karena itu, setiap program pemulihan ekonomi yang ditujukan mengentaskan fakir miskin, harus ditujukan kepada mereka yang tergolong pada kelompok tadi. Baik orang tersebut memiliki pekerjaan, tetapi tetap tidak dapat memenuhi kebutuhan pokoknya dengan cara yang makruf, yakni fakir, maupun yang tidak memiliki pekerjaan karena PHK atau sebab lainnya, yakni miskin.

Jika tolok ukur kemiskinan Islam dibandingkan dengan tolok ukur lain, maka akan didapati perbedaan yang sangat mencolok. Tolok ukur kemiskinan dalam Islam memiliki nilai yang jauh lebih tinggi dari tolok ukur lain. Sebab, tolok ukur kemiskin- 
an dalam Islam mencakup tiga aspek pemenuhan kebutuhan pokok bagi individu manusia, yaitu pangan, sandang, dan pangan. Adapun tolok ukur lain umumnya hanya menitikberatkan pada pemenuhan kebutuhan pangan semata.

Banyak ragam pendapat mengenai sebab-sebab kemiskinan. Namun, secara garis besar dapat dikatakan ada tiga sebab utama kemiskinan. Pertama, kemiskinan alamiah, yaitu kemiskinan yang disebabkan oleh kondisi alami seseorang; misalnya cacat mental atau fisik, usia lanjut sehingga tidak mampu bekerja, dan lain-lain. Kedua, kemiskinan kultural, yaitu kemiskinan yang disebabkan oleh rendahnya kualitas SDM akibat kultur masyarakat tertentu; misalnya rasa malas, tidak produktif, bergantung pada harta warisan, dan lain-lain. Ketiga, kemiskinan stuktural, yaitu kemiskinan yang disebabkan oleh kesalahan sistem yang digunakan negara dalam mengatur urusan rakyat.

Dari tiga sebab utama tersebut, yang paling besar pengaruhnya adalah kemiskinan stuktural. Sebab, dampak kemiskinan yang ditimbulkan bisa sangat luas dalam masyarakat. Kemiskinan jenis inilah yang menggejala di berbagai negara dewasa ini. Tidak hanya di negara-negara sedang berkembang, tetapi juga di negara-negara maju.

Kesalahan negara dalam mengatur urusan rakyat, hingga menghasilkan kemiskinan struktural, disebabkan oleh penerapan sistem Kapitalisme yang memberikan kesalahan mendasar dalam beberapa hal, antara lain Peran Negara. Menurut pandangan kapitalis, peran negara secara langsung di bidang sosial dan ekonomi, harus diupayakan seminimal mungkin. Bahkan, diharapkan negara hanya berperan dalam fungsi pengawasan dan penegakan hukum semata. Lalu, yang berperan secara langsung menangani masalah sosial dan ekonomi adalah masyarakat itu sendiri atau swasta. Karena itulah, dalam masyarakat kapitalis kita jumpai banyak sekali yayasan-yayasan. Di antaranya ada yang bergerak dibidang sosial, pendidikan, dan sebagainya. Selain itu, kita jumpai pula banyak program swastanisasi badan usaha milik negara.

Peran negara semacam ini, jelas telah menjadikan negara kehilangan fungsi utamanya sebagai pemelihara urusan rakyat. Negara juga akan kehilangan kemampuannya dalam menjalankan fungsi pemelihara urusan rakyat. Akhirnya, rakyat dibiarkan berkompetisi secara bebas dalam masyarakat. Realitas adanya orang yang kuat dan yang lemah, yang sehat dan yang cacat, yang tua dan yang muda, dan sebagainya, diabaikan sama sekali. Yang berlaku kemudian adalah hukum rimba, siapa yang kuat dia yang menang dan berhak hidup.

Kesenjangan kaya miskin di dunia saat ini adalah buah dari diterapkannya sistem Kapitalisme yang sangat individualis itu. Dalam pandangan kapitalis, penanggulangan kemiskinan merupakan tanggung jawab si miskin itu sendiri, kemiskinan bukan merupakan beban bagi umat, negara, atau kaum hartawan. Sudah saatnya kita mencari dan menerapkan sistem alternatif selain Kapitalisme, tanpa perlu ada tawar-menawar lagi.

Dalam perspektif Islam, kemiskinan timbul karena berbagai sebab struktural. Pertama, kemiskinan timbul karena kejahatan manusia terhadap alam (QS Ar Ruum[30]:41) 
Ekonomika-Bisnis Vol. 4 No.2 Bulan Juli Tahun 2013. Hal 101-112

"Telah nampak kerusakan di darat dan di laut disebabkan karena perbuatan tangan manusia, supaya Allah merasakan kepada mereka sebahagian dari (akibat) perbuatan mereka, agar mereka kembali (ke jalan yang benar)."sehingga manusia itu sendiri yang kemudian merasakan dampak-nya (QS Asy Syura [42]:30).

"Dan apa musibah yang menimpa kamu maka adalah disebabkan oleh perbuatan tanganmu sendiri, dan Allah memaafkan sebagian besar (dari kesalahan-kesalahanтu)."

Kedua, kemiskinan timbul karena ketidakpedulian dan kebakhilan kelompok kaya (QS Ali Imran [3]: 180)

"Sekali-kali janganlah orang-orang yang bakhil dengan harta yang Allah berikan kepada mereka dari karuniaNya menyangka, bahwa kebakhilan itu baik bagi mereka. Sebenarnya kebakhilan itu adalah buruk bagi mereka. Harta yang mereka bakhilkan itu akan dikalungkan kelak di lehernya di hari kiamat. Dan kepunyaan Allah-lah segala warisan (yang ada) di langit dan di bumi. Dan Allah mengetahui apa yang kamu kerjakan" (QS Al Ma'aarij [70]:18)

"Serta mengumpulkan (harta benda) lalu menyimpannya"sehingga si miskin tidak mampu keluar dari lingkaran kemiskinan.

Ketiga, kemiskinan timbul karena sebagian manusia bersikap dzalim, eksploitatif, dan menindas kepada sebagian manusia yang lain, seperti memakan harta orang lain dengan jalan yang batil (QS At Taubah [9]:34)

"Hai orang-orang yang beriman, sesungguhnya sebahagian besar dari orang-orang alim Yahudi dan rahib-rahib
Nasrani benar-benar memakan harta orang dengan jalan yang batil dan mereka menghalang-halangi (manusia) dari jalan Allah. Dan orang-orang yang menyimpan emas dan perak dan tidak menafkahkannya pada jalan Allah, maka beritahukanlah kepada mereka, (bahwa mereka akan mendapat) siksa yang pedih" memakan harta anak yatim (QS An Nisaa' [4]: 2, 6, 10),

"Dan berikanlah kepada anak-anak yatim (yang sudah balig) harta mereka, jangan kamu menukar yang baik dengan yang buruk dan jangan kamu makan harta mereka bersama hartamu. Sesungguhnya tindakan-tindakan (menukar dan memakan) itu, adalah dosa yang besar"

"Dan ujilah anak yatim itu sampai mereka cukup umur untuk kawin. Kemudian jika menurut pendapatmu mereka telah cerdas (pandai memelihara harta), maka serahkanlah kepada mereka harta-hartanya. Dan janganlah kamu makan harta anak yatim lebih dari batas kepatutan dan (janganlah kamu) tergesa-gesa (membelanjakannya) sebelum mereka dewasa. Barang siapa (di antara pemelihara itu) mampu, maka hendaklah ia menahan diri (dari memakan harta anak yatim itu) dan barang siapa miskin, maka bolehlah ia makan harta itu menurut yang patut. Kemudian apabila kamu menyerahkan harta kepada mereka, maka hendaklah kamu adakan saksi-saksi (tentang penyerahan itu) bagi mereka. Dan cukuplah Allah sebagai Pengawas (atas persaksian itu)"

"Sesungguhnya orang-orang yang memakan harta anak yatim secara lalim, sebenarnya mereka itu menelan api 
sepenuh perutnya dan mereka akan masuk ke dalam api yang menyala-nyala (neraka)."dan memakan harta riba (QS Al Baqarah [2]:275):

"Orang-orang yang makan (mengambil) riba tidak dapat berdiri melainkan seperti berdirinya orang yang kemasukan setan lantaran (tekanan) penyakit gila. Keadaan mereka yang demikian itu, adalah disebabkan mereka berkata (berpendapat), sesungguhnya jual beli itu sama dengan riba, padahal Allah telah menghalalkan jual beli dan mengharamkan riba. Orang-orang yang telah sampai kepadanya larangan dari Tuhannya, lalu terus berhenti (dari mengambil riba), maka baginya apa yang telah diambilnya dahulu (sebelum datang larangan); dan urusannya (terserah) kepada Allah. Orang yang mengulangi (mengambil riba), maka orang itu adalah penghuni-penghuni neraka; mereka kekal di dalamnya."

Keempat, kemiskinan timbul karena konsentrasi kekuatan politik, birokrasi, dan ekonomi di satu tangan. Hal ini tergambar dalam kisah Fir'aun, Haman, dan Qarun yang bersekutu dalam menindas rakyat Mesir di masa hidup Nabi Musa (QS Al Qashash [28]:1-88).

Kelima, kemiskinan timbul karena gejolak eksternal seperti bencana alam atau peperangan sehingga negeri yang semula kaya berubah menjadi miskin. Bencana alam yang memiskinkan ini seperti yang menimpa kaum Saba (QS Saba' [34]: 1415)

"Maka tatkala Kami telah menetapkan kematian Sulaiman, tidak ada yang menunjukkan kepada mereka kematian- nya itu kecuali rayap yang memakan tongkatnya. Maka tatkala ia telah tersungkur, tahulah jin itu bahwa kalau sekiranya mereka mengetahui yang gaib tentulah mereka tidak tetap dalam siksa yang menghinakan.

'Sesungguhnya bagi kaum Saba' ada tanda (kekuasaan Tuhan) di tempat kediaman mereka yaitu dua buah kebun di sebelah kanan dan di sebelah kiri. (Kepada mereka dikatakan): "Makanlah olehmu dari rezeki yang (dianugerahkan) Tuhanmu dan bersyukurlah kamu kepada-Nya. (Negerimu) adalah negeri yang baik dan (Tuhanmu) adalah Tuhan Yang Maha Pengampun".atau peperangan yang menciptakan para pengungsi miskin yang terusir dari negeri-nya (QS Al Hasyr [59]:8-9):

"(Juga) bagi para fakir yang berhijrah yang diusir dari kampung halaman dan dari harta benda mereka (karena) mencari karunia dari Allah dan keridaan (Nya) dan mereka menolong Allah dan Rasul-Nya. Mereka itulah orang-orang yang benar"

"Dan orang-orang yang telah menempati Kota Madinah dan telah beriman (Ansar) sebelum (kedatangan) mereka (Muhajirin), mereka mencintai orang yang berhijrah kepada mereka. Dan mereka tiada menaruh keinginan dalam hati mereka terhadap apa-apa yang diberikan kepada mereka (orang Muhajirin); dan mereka mengutamakan (orang-orang Muhajirin), atas diri mereka sendiri. Sekalipun mereka memerlukan (apa yang mereka berikan itu). Dan siapa yang dipelihara dari kekikiran dirinya, mereka itulah orangorang yang beruntung." 


\section{Strategi Pengentasan Kemiskinan Dalam Perspektif Islam}

Dengan memahami akar masalah, akan lebih mudah bagi kita untuk memahami fenomena kemiskinan yang semakin meraja di sekeliling kita. Akar kemiskinan di negeri ini adalah perilaku eksploitatif akibat penerapan bunga sehingga kita setiap tahunnya harus menghabiskan sebagian besar anggaran negara untuk membayar bunga utang dan sektor riil harus collapse tercekik bunga tinggi perbankan. Akar kemiskinan di negeri ini adalah birokrasi yang korup dan pemusatan kekuasaan di tangan kekuatan politik dan pemilik modal sehingga tidak jelas lagi mana kepentingan publik dan mana kepentingan pribadi. Akar kemiskinan di negeri ini adalah buah dari kejahatan kita terhadap lingkungan yang kita rusak sedemikian masif dan ekstensif.

Strategi Pengentasan Kemiskinan Islammemiliki berbagai prinsip-prinsip terkait kebijakan publik yang dapat dijadikan panduan bagi program pengentasan kemiskinan dan sekaligus penciptaan lapangan kerja (Wibisono, 2010), yaitu:

Pertama, Islam mendorong pertumbuhan ekonomi yang memberi manfaat luas bagi masyarakat (pro-poor growth). Islam mencapai pro-poor growth melalui dua jalur utama: pelarangan riba dan mendorong kegiatan sektor riil. Pelarangan riba secara efektif akan mengendalikan inflasi sehingga daya beli masyarakat terjaga dan stabilitas perekonomian tercipta. Pada saat yang sama, Islam mengarahkan modal pada kegiatan ekonomi produktif melalui kerjasama ekonomi dan bisnis seperti mudharabah, muara'ah, dan musaqat. Dengan demikian, tercipta keselarasan antara sektor riil dan moneter sehingga pertumbuhan ekonomi dapat berlangsung secara berkesinambungan.

Kedua, Islam mendorong penciptaan anggaran negara yang memihak kepada kepentingan rakyat banyak (pro-poor budgeting). Dalam sejarah Islam, terdapat tiga prinsip utama dalam mencapai pro-poor budgeting yaitu: disiplin fiskal yang ketat, tata kelola pemerintahan yang baik, dan penggunaan anggaran negara sepenuhnya untuk kepentingan publik. Tidak pernah terjadi defisit anggaran dalam pemerintahan Islam walau tekanan pengeluaran sangat tinggi, kecuali sekali pada masa pemerintahan Nabi Muhammad karena perang. Yang lebih banyak didorong adalah efisiensi dan penghematan anggaran melalui good governance.

Di dalam Islam, anggaran negara adalah harta publik sehingga anggaran menjadi sangat responsif terhadap kepentingan orang miskin, seperti menyediakan makanan, membayar biaya penguburan dan utang, memberipinjaman tanpa bunga untuk tujuan komersial, dan beasiswa bagi yang belajar agama.

Ketiga, Islam mendorong pembangunan infrastruktur yang memberi manfaat luas bagi masyarakat (pro-poor infrastructure). Islam mendorong pembangunan infrastruktur yang memiliki dampak eksternalitas positif dalam rangka meningkatkan kapasitas dan efisiensi perekonomian. Nabi Muhammad SAW membagikan tanah di Madinah kepada masyarakat untuk membangun perumahan, mendirikan pemandian umum disudut kota, membangun pasar, memperluas jaringan jalan, dan memperhatikan jasa pos.

Khalifah Umar bin Khattab membangun kota Kufah dan Basrah dengan memberi perhatian besar pada infrastruktur dan tata ruang kota. Beliau juga memerin- 
tahkan Gubernur Mesir, Amr bin Ash, untuk mempergunakan sepertiga penerimaan Mesir untuk pembangunan jembatan, kanal, dan jaringan air bersih.

Keempat, Islammendorong penyediaan pelayanan publik dasar yang berpihak pada masyarakat luas (pro-poor public services). Terdapat tiga bidang pelayanan publik yang mendapat perhatian Islam secara serius: birokrasi, pendidikan, dan kesehatan. Di dalam Islam, birokrasi adalah amanah untuk melayani publik, bukan untuk kepentingan diri sendiri atau golongan.

Khalifah Usman tidak mengambil gaji dari kantor-nya. KhalifahAli membersihkan birokrasi dengan memecat pejabat-pejabat pubik yang korup. Selain itu, Islam juga mendorong pembangunan pendidikan dan kesehatan sebagai sumber produktivitas untuk pertumbuhan ekonomi jangka panjang. Nabi Muhammad SAW meminta tebusan bagi tawanan perang dengan mengajarkan baca tulis kepada masyarakat. Nabi Muhammad juga menyuruh masyarakat berperilaku hidup bersih dan memerintahkan agar orang sakit dikarantina hingga sembuh untuk mencegah penyebaran penyakit.

Kelima, Islam mendorong kebijakan pemerataan dan distribusi pendapatan yang memihak rakyat miskin (pro-poor income distribution). Terdapat tiga instrumen utama dalam Islam terkait distribusi pendapatan yaitu aturan kepemilikan tanah, penerapan zakat, serta menganjurkan qardul hasan, infak, dan wakaf. Islam mengatur bagi setiap orang yang menghidupkan tanah mati, maka tanah itu menjadi miliknya. Dan bagi siapa saja yang menelantarkan tanahnya, maka negara berhak mengambilnya untuk kemudian memberikan kepada orang lain yang siap mengolah-nya. Dengan penerapan zakat, maka tidak akan ada konsentrasi harta pada sekelompok masyarakat. Zakat juga memastikan bahwa setiap orang akan mendapat jaminan hidup minimum sehingga memiliki peluang untuk keluar dari kemiskinan. Lebih jauh lagi, untuk memastikan bahwa harta tidak hanya beredar di kalangan orang kaya saja, Islam juga sangat mendorong orang kaya untuk memberikan qard, infak, dan wakaf.

Firman Allah SWT dalam surat AlAraf ayat 180: "Allah mempunyai asmaul husna, maka bermohonlah kepadaNya dengan menyebut asmaul husna itu dan tinggalkanlah orang-orang yang menyimpang dari kebenaran dalam (menyebut) nama-namaNya. Nanti mereka akan mendapat balasan terhadap apa yang telah mereka kerjakan".

Berdasar buku Tafsir Manajemen Bisnis Seri Detak Asma'ul Husna (Dr. H. Khairul Alwan Ar-Riva'i Nasution, MM) bagian ke 79 (hal 241-269) sebagai umat muslim, untuk menerapkan strategi pengentasan kemiskinan dalam perspektif Islam, adalah dengan meneladani sifat $\mathrm{Al}$ lah SWT yaitu Al Barr (Yang Maha Dermawan).

Di dalam surat At Thur (52) ayat 2728 gambaran tentang sifat Al Barr ini digandengkan dengan sifat Ar Rahim yaitu:

\section{"Maka Allah memberikan karunia} kepada kami dan memelihara kami dari azab neraka. Sesungguhnya kami dahulu menyembah-Nya. Sesungguhnya Dia-lah yang melimpahkan kebaikan lagi Maha Penyayang"

Penggandengan sifat Al barr dengan Ar Rahim adalah bahwa kedermawanan Allah SWT tidak didasarkan oleh suatu pamrih, tetapi kedermawanan Allah didasarkan semata-mata karena kasih sayang NYA kepada hamba-NYA. 
Salah satu strategi pengentasan kemiskinan Islamadalah mendorong orang kaya untuk memberikan qard, infak, dan wakaf. Untuk memberikan qard, infak, dan wakaf perlu dibangun sifat dermawan tersebut. Upaya dan ikhtiar untuk mencontoh dan meneladani sifat Al Barr ini sangat penting, sebagaimana dapat ditemui dalam surat Al Baqarah (2) ayat 261-262: "Perumpamaan (nafkah yang dikeluarkan oleh) orang-orang yang menafkahkan hartanya di jalan Allah adalah serupa dengan sebutir benih yang menumbuhkan tujuh bulir, pada tiap-tiap bulir: seratus biji. Allah melipat gandakan (ganjaran) bagi siapa yang Dia kehendaki. Dan Allah Maha Luas (karuniaNya) lagi Maha Mengetahui."

"Orang-orang yang menafkahkan hartanya di jalan Allah, kemudian mereka tidak mengiringi apa yang dinafkahkannya itu dengan menyebutnyebut pemberiannya dan dengan tidak menyakiti (perasaan si penerima), mereka memperoleh pahala di sisi Tuhan mereka. Tidak ada kekhawatiran terhadap mereka dan tidak (pula) mereka bersedih hati"

Sifat kedermawanan akan bermakna positif jika kedermawanan itu dilakukan dengan niat dan motivasi yang ikhlas. Bahkan dalam salah satu Hadits Nabi Muhammad SAW dijelaskan jangan sampai tangan kiri mengetahui apa yang diberikan oleh tangan kanan. Implementasi kedermawanan yang melekat menjadikan antara yang memberi dan menerima dalam ikatan kasih sayang yang dinafasi oleh kelemahlembutan dan sikap tolong menolong.

\section{Penutup}

Islam memandang bahwa masalah kemiskinan adalah masalah tidak terpenuhinya kebutuhan-kebutuhan primer secara menyeluruh. Syariat Islam telah menentukan kebutuhan primer itu (yang menyangkut eksistensi manusia) berupa tiga hal, yaitu sandang, pangan, dan papan. Dalam perspektif Islam, kemiskinan timbul karena berbagai sebab struktural. Pertama, kemiskinan timbul karena kejahatan manusia terhadap alam; Kedua, kemiskinan timbul karena ketidakpedulian dan kebakhilan kelompok kaya; Ketiga, kemiskinan timbul karena sebagian manusia bersikap dzalim, eksploitatif, dan menindas kepada sebagian manusia yang lain, seperti memakan harta orang lain dengan jalan yang batil; Keempat, kemiskinan timbul karena konsentrasi kekuatan politik, birokrasi, dan ekonomi di satu tangan. Hal ini tergambar dalam kisah Fir' aun, Haman, dan Qarun yang bersekutu dalam menindas rakyat Mesir di masa hidup Nabi Musa; Kelima, kemiskinan timbul karena gejolak eksternal seperti bencana alam atau peperangan sehingga negeri yang semula kaya berubah menjadi miskin. Bencana alam yang memiskinkan ini seperti yang menimpa kaum Saba.

Strategi Pengentasan Kemiskinan Islam memiliki berbagai prinsip-prinsip terkait kebijakan publik yang dapat dijadikan panduan bagi program pengentasan kemiskinan dan sekaligus penciptaan lapangan kerja (Wibisono, 2010), yaitu: Pertama, Islam mendorong pertumbuhan ekonomi yang memberi manfaat luas bagi masyarakat (pro-poor growth). Islam mencapai pro-poor growth melalui dua jalur utama: pelarangan riba dan mendorong 
kegiatan sektor riil; Kedua, Islam mendorong penciptaan anggaran negara yang memihak kepada kepentingan rakyat banyak (pro-poor budgeting). Dalam sejarah Islam, terdapat tiga prinsip utama dalam mencapai pro-poor budgeting yaitu: disiplin fiskal yang ketat, tata kelola pemerintahan yang baik, dan penggunaan anggaran negara sepenuhnya untuk kepentingan publik; Ketiga, Islam mendorong pembangunan infrastruktur yang memberi manfaat luas bagi masyarakat (pro-poor infrastructure). Islam mendorong pembangunan infrastruktur yang memiliki dampak eksternalitas positif dalam rangka meningkatkan kapasitas dan efisiensi perekonomian; Keempat, Islam mendorong penyediaan pelayanan publik dasar yang berpihak pada masyarakat luas (pro-poor public services). Terdapat tiga bidang pelayanan publik yang mendapat perhatian Islam secara serius: birokrasi, pendidikan, dan kesehatan. Di dalam Islam, birokrasi adalah amanah untuk melayani publik, bukan untuk kepentingan diri sendiri atau golongan; Kelima, Islam mendorong kebijakan pemerataan dan distribusi pendapatan yang memihak rakyat miskin (pro-poor income distribution). Terdapat tiga instrumen utama dalam Islam terkait distribusi pendapatan yaitu aturan kepemilikan tanah, penerapan zakat, serta menganjurkan qardul hasan, infak, dan wakaf.

\section{DAFTAR PUSTAKA}

Ghopur, Abdul. 2010. Indonesia dan Problem Kemiskinan, www.suarapembaca.com, diakses pada tanggal 16 Desember 2012

Nasution, Khairul Alwan. 2010. Tafsir Manajemen Bisnis Seri Detak Asmaul Husna. Penerbit Yayasan Amin. Jakarta Selatan.

Nata, Abuddin, dkk. 2008. Kajian Tematik Al-Quran tentang Konstruksi Sosial. Penerbit Angkasa Raya. Bandung.

Rais, M. Amien. 1998. Tauhid Sosial; Formula Menggempur Kesenjangan, Penerbit Mizan. Bandung.

Rakhmat, Jalaluddin. 1998. Islam Alternatif: Ceramah-ceramah di Kampus. Penerbit Mizan. Bandung.

Siahaan, N.H.T. 2004. Hukum Lingkungan dan Ekologi Pembangunan. Penerbit Erlangga. Jakarta.

Shihab, M. Quraish. 1996. Wawasan alQuran. Penerbit Mizan. Bandung.

Suroyo, Al, dkk. 2006. Agama dan Kepercayaan membawa Pembaruan. Penerbit Kanisius. Jogjakarta. 
